University of Nebraska - Lincoln

DigitalCommons@University of Nebraska - Lincoln

Publications from USDA-ARS / UNL Faculty

U.S. Department of Agriculture: Agricultural

Research Service, Lincoln, Nebraska

$1-2003$

\title{
Registration of the Maize Population Zapalote Chico 2451F
}

N. W. Widstrom

USDA-ARS, brts@gnv.ifas.ufl.edu

B. R. Wiseman

USDA

M. E. Snook

USDA

G. S. Nuessly

University of Florida

B. T. Scully

University of Florida

Follow this and additional works at: https://digitalcommons.unl.edu/usdaarsfacpub

Widstrom, N. W.; Wiseman, B. R.; Snook, M. E.; Nuessly, G. S.; and Scully, B. T., "Registration of the Maize Population Zapalote Chico 2451F" (2003). Publications from USDA-ARS / UNL Faculty. 1863.

https://digitalcommons.unl.edu/usdaarsfacpub/1863

This Article is brought to you for free and open access by the U.S. Department of Agriculture: Agricultural Research Service, Lincoln, Nebraska at DigitalCommons@University of Nebraska - Lincoln. It has been accepted for inclusion in Publications from USDA-ARS / UNL Faculty by an authorized administrator of DigitalCommons@University of Nebraska - Lincoln. 
This document is a U.S. government work and is not subject to copyright in the United States.

\section{Registration of the Maize Population Zapalote Chico 2451F}

Zapalote Chico 2451F (ZC-2451F) (Reg. no. GP-370, PI 618810), a maize (Zea mays L.) germplasm population was released in April 2001 by the Florida Agricultural Experiment Station and the USDA-ARS Crop Genetics and Breeding Research Unit. This population was released as a source of improved resistance to silk and ear feeding by larvae of the corn silk fly [Euxesta stigmatias Loew. (Diptera: Otitidae)], the fall armyworm [Spodoptera frugiperda (J.E. Smith)], and the corn earworm [Heliocoverpa zea (Boddie) (Lepidoptera: Noctuidae)]. Zapalote Chico $2451 \mathrm{~F}$ is distinct from Shrunken Zapalote Chico (ZC-sh2) (PI 612343), and the Zapalote Chico land race collected in the state of Oaxaca, Mexico, in the late 1940s, and first acceded to the National Seed Storage Laboratory as PI 217413 (Scully et al., 2000; Anderson, 1959; Straub and Fairchild, 1970). PI 217413 was one of the earliest Zapalote Chico populations identified as a source of natural compounds with insecticidal properties (Wais et al., 1979; Wilson and Wiseman, 1988). Resistance in Zapalote Chico 2451F is also due to elevated levels of the flavone glycoside maysin that is found in fresh silk (Ellinger et al., 1980; Snook et al., 1993, 1995). Maysin is synthesized in the flavonoid pathway and known to specifically confer antibiosis-based resistance to silk feeding (Byrne et al., 1996).

Zapalote Chico $2451 \mathrm{~F}$ is one of several subpopulations derived from Oaxaca Gpo. 35, a Zapalote Chico population held at CIMMYT, Mexico (A. Ortega, 1968, personal communication). Zapalote Chico $2451 \mathrm{~F}$ was developed from two phases of selection. In the first phase, three cycles of recurrent mass selection were conducted in Tifton, GA, on Oaxaca Gpo. 35, which resulted in a germplasm line coded as ZC 2451 (P)C3. Selection was practiced primarily for a plant with a purple phenotype; secondary selection criteria emphasized agronomic traits such as plant uniformity, seedling vigor, and tight husks. Subsequently, ZC 2451 (P)C3, along with an array of other Zapalote Chico accessions, were assessed for resistance to silk and ear feeding by lepidopteran larvae. After the identification of improved insect resistance, ZC 2451 (P)C3 underwent another three cycles of phenotypic recurrent mass selection in Florida from 1995 to 1997. In different generations, selection was practiced at variable intensities of 2.063 to 1.554 (5-15\%) for resistance to ear and silk feeding by the corn silk fly and fall armyworm. This selection program resulted in the Zapalote Chico $2451 \mathrm{~F}$ population.

In Florida, Zapalote Chico $2451 \mathrm{~F}$ was compared with the sweet corn hybrid Primetime, the Bt test hybrid GSS 0966 with the Cry $1 A(b)$ construct, and ZC-sh2. At silk emergence, corn silk fly larvae were infested on freshly emergent silk with ear damage rated at roasting stage $( \pm 21 \mathrm{DAP})$ on a 0 to 4 scale (Scully et al., 2002). Results from 1998 to 2000 indicated that Zapalote Chico 2451F and ZC-sh2 sustained ear damage rated at 1.31 and 1.49 , respectively, and were significantly more resistant than either GSS 0966 or Primetime, each rated at 2.45 and 2.56 , respectively. Silk infestation with neonate and/or first instar fall armyworm during the same time period revealed that GSS 0966, ZC-sh2, and Zapalote Chico 2451F were comparable and rated at $1.83,1.78$, and 1.73 , respectively, on a 0 to 3 damage scale. The susceptible check, Primetime, incurred an average damage rating of 2.58. Damage caused by corn earworm in Georgia on GSS 0966, Zapalote Chico $2451 \mathrm{~F}$, and ZC 2451 (P)C3 was not significantly different and rated at $2.35,2.52$, and 2.83 , respectively. Corn earworm damage to Primetime averaged 7.00, while ZC-sh2 sustained an average damage rating of 4.70 .

Levels of silk maysin were assayed and compared for Primetime, GSS 0966, ZC-sh2, Zapalote Chico 2451F, along with 
ZC 2451 (P)C3 on plants grown in Georgia. On the basis of fresh silk weights, ZC-sh2, Zapalote Chico $2451 \mathrm{~F}$, and ZC 2451 (P)C3 had 1.02, 0.52, and $0.49 \%$ maysin, respectively. All three were significantly different. As expected, the maysin assay in Primetime and GSS 0966 was near zero.

In Florida, the Zapalote Chico $2451 \mathrm{~F}$ population averaged $180 \mathrm{~cm}$ in height with ears placed $53 \mathrm{~cm}$ above the ground, and reached midsilking in $62 \mathrm{~d}, 3 \mathrm{~d}$ earlier than Primetime. Mature plants had 8 to 11 leaves at silk expression with mostly five leaves above the top ear. Brace roots were present, but not prolific, on stalks with a basal diameter up to $2.0 \mathrm{~cm}$. Tillers were absent. Internode width at the top ear ranged from 1.7 to $2.2 \mathrm{~cm}$, with internode lengths of 14.0 to $20.0 \mathrm{~cm}$. Leaves at the top ear of Zapalote Chico 2451F measured 63 to $76 \mathrm{~cm}$ in length with leaf widths of 7.0 to $8.0 \mathrm{~cm}$. Leaves at the ear node angled $45^{\circ}$ and were pendulant toward the tip, usually with five or more marginal waves and few longitudinal creases. Husk leaves on Zapalote Chico $2451 \mathrm{~F}$ generally ranged from 13.0 to $15.0 \mathrm{~cm}$, but occasionally up to $20 \mathrm{~cm}$, with two to three of these husks wrapped completely around the ear. Husk leaves clasped tightly around the ear and at the tip. Flag leaves were mostly absent. Husk leaf lengths measured 17.0 to $20.0 \mathrm{~cm}$ and extended 1.0 to $2.0 \mathrm{~cm}$ beyond the ear tip. The Zapalote Chico $2451 \mathrm{~F}$ population is suffused with deep purple and reddish pigmentation throughout most plant organs.

Ears measured 8.0 to $10.5 \mathrm{~cm}$ in length, and up to $4.0 \mathrm{~cm}$ in width on cobs that averaged $2.7 \mathrm{~cm}$ wide. Ears were held on the stalk at a $15^{\circ}$ to $30^{\circ}$ angle. Kernel formation on the ear was distinct, with dropped rows at the base of the ear. Majority row count was 14 and commonly ranged from 10 to 16. Shank length measured between 5.0 and $7.0 \mathrm{~cm}$ with 7 to 8 internodes. White floury kernels taken from the mid-ear region measured $0.80 \mathrm{~cm}$ in length, $0.40 \mathrm{~cm}$ in width, and had an average kernel height of nearly $0.99 \mathrm{~cm}$. Zapalote Chico $2451 \mathrm{~F}$ was susceptible to the common races of blight and rust diseases found in Florida.

This Zapalote Chico $2451 \mathrm{~F}$ population is part of a series of high maysin populations that include ZC-sh2, the popcorn accession PI 340856, EPM6 (PI 614735) with a semipopcorn type purple kernel, and SIM6 (PI 614736) with a yellow dent kernel on a red cob. (Scully et al., 2000; Widstrom and Snook, 2001, 2002). Zapalote Chico $2451 \mathrm{~F}$ is publicly released with the request that recipients of this seed acknowledge the source when using this germplasm in either research or crop improvement. In addition to storage at the National Seed Storage Laboratory, seed stock will be maintained and is available from N.W. Widstrom or B.T. Scully at their respective addresses.

N.W. Widstrom,* B.R. Wiseman, M.E. Snook, G.S. Nuessly, And B.T. Scully

\section{References}

Anderson, E. 1959. Zapalote Chico: An important chapter in the history of maize and man. p. 230-237. In Actas del Congr. Int. de Americanistas, 33, San Jose, Costa Rica. 20-27 July 1958. Lehmann, Brooklyn, NY.

Byrne, P.F., M.D. McMullen, M.E. Snook, T.A. Musket, J.M. Theuri, N.W. Widstrom, B.R. Wiseman, and E.H. Coe. 1996. Quantitative trait loci and metabolic pathways: Genetic control of concentration of maysin, a corn earworm resistance factor, in maize silks. Proc. Natl. Acad. Sci. USA 93:8820-8825.

Ellinger, C.A., B.G. Chan, A.C. Waiss, Jr., R.E. Lundin, and W.F. Haddon. 1980. C-Glycosylflavones from Zea mays that inhibit insect development. Phytochemistry 19:293-297.

Scully, B.T., G.S. Nuessly, R.L. Beiriger, N.W. Widstrom, and M.E. Snook. 2000. Registration of the maize population: 'Shrunken Zapalote Chico'. Crop Sci. 40:1837-1838.

Scully, B.T., G.S. Nuessly, M.G. Hentz, and R.L. Beiriger. 2002. A rating scale to assess damage caused by the corn silk fly [Euxesta stigimatias (Loew.) (Diptera:Otitidae)] on the ears of sweet corn. Subtrop. Plant Sci. 55:(in press).

Snook, M.E., R.C. Gueldner, N.W. Widstrom, B.R. Wiseman, D.S. Himmels-bach, J.S. Harwood, and C.E. Costello. 1993. Levels of maysin and maysin analogues in silks of maize germplasm. J. Agric. Food Chem. 41:1481-1485.

Snook, M.E., N.W. Widstrom, B.R. Wiseman, P.F. Byrne, J.S. Harwood, and C.E. Costello. 1995. New C- 4"-Hydroxy derivatives of maysin and 3'-Methoxy-maysin isolated from corn silks (Zea mays). J. Agric. Food Chem. 43:2740-2745.

Straub, R.W., and M.L. Fairchild. 1970. Laboratory studies of resistance in corn to the corn earworm. J. Econ. Entomol. 63:1901-1903.

Wais, A.C., B.G. Chan, C.A. Ellinger, B.R. Wiseman, W.W. McMillian, N.W. Widstrom, M.S. Zuber, and A.J. Keaster. 1979. Maysin, a flavone glycoside from corn silks with an antibiotic activity toward corn earworm. J. Econ Ent. 72:256-258.

Widstrom, N.W., and M.E. Snook. 2001. Registration of EPM6 and SIM6 maize germplasm, high silk maysin sources of resistance to corn earworm. Crop Sci. 41:2009-2010.

Widstrom, N.W., and M.E. Snook. 2002. Recurrent selection for maysin concentration in maize silks antibiotic to earworms. Plant Breed. 120:357-359.

Wilson, R.L., and B.R. Wiseman. 1988. Field and laboratory evaluation of selected maize plant introductions for corn earworm responses at two locations. Maydica 33:179-187.

N.W. Widstrom, USDA-ARS-CGBRU, P.O. Box 748, Tifton, GA 31793; B.R. Wiseman, USDA (retired), and M.E. Snook,USDA (retired), Russell Research Center, P.O. Box 5677, Athens, GA 30605; and B.T. Scully and G.S. Nuessly, EREC-IFAS, Univ. of Florida, Box 8003, Belle Glade, FL 33430. Contribution of the Florida Agric. Exp. Stn. in cooperation with the USDA-ARS, Florida Agric. Exp. Stn. Journal Series No. R-08022. This research was supported by the NE124 Regional Hatch Project, Novartis Vegetable Seed Co., Florida Foundation Seed Producers, Inc. Registration by CSSA. Accepted 29 Apr. 2002. *Corresponding author (brts@gnv.ifas.ufl.edu).

Published in Crop Sci. 42:444-445 (2003). 